\title{
DIGLOSIA
}

Terakreditasi Sinta 3 | Volume 3 | Nomor 3 | Tahun 2020 | Halaman 331-340

P-ISSN 2615-725X | E-ISSN 2615-8655

http://diglosiaunmul.com/index.php/diglosia/article/view/69

\section{PENYEMPITAN MAKNA AMELIORATIF PADA NOMINA DALAM BAHASA INGGRIS}

\author{
Ameliorative Semantic Narrowing of Noun Words in the English Language
}

\author{
Erlan Aditya Ardiansyah \\ Fakultas Adab dan Humaniora \\ UIN Sunan Gunung Djati Bandung \\ Pos-el korespondensi: erlanaditiya@uinsgd.ac.id
}

\begin{abstract}
Semantic change is a language phenomenon which may be found in a society. A kind of semantic change which which is remarkable to be examined is semantic narrowing. A positive meaning namely amelioration may be discovered through semantic narrowing. In addition, semantic narrowing in English is frequently discovered $i$ nouns. Therefore, factors which can stimulate the process are necessary to be elaborated. Aim of the study was to examine nouns' ameliorative semantic narrowing in English. Methods applied in the study were descriptive synchronicdiachronic methods. The methods were used to describe portrayal relating to the condition in past and present. Data in the study were six nouns which were collected from the video clips relayed on the television programs. Semantic narrowing found in the study were caused by several factors: (a), meaning change due to environmental change (b) meaning change due to language users' response, and (c) meaning change due to association. The results showed that semantic narrowing has a correlation with homonymy and polysemy. Therefore, meaning change may have related or non-related meaning from the previous meaning. Longer period of the process and the society agreement have become challanges which should be realized due to acceptance of the new meaning.
\end{abstract}

Keywords: amelioration, semantic narrowing, semantic change

\begin{abstract}
Abstrak: Perubahan makna adalah fenomena kebahasaan yang kerap ditemui pada suatu kelompok masyarakat. Salah satu jenis perubahan makna yang menarik untuk dianalisis adalah penyempitan makna. Penyempitan makna dapat mengarah pada makna positif atau yang dikenal dengan istilah ameliorasi. Tidak jarang nomina dalam bahasa Inggris yang mengalami penyempitan makna. Selain itu, faktor-faktor yang dapat menstimulasi penyempitan makna itu perlu untuk dijelaskan. Tujuan penelitian ini untuk menganalisis nomina dalam bahasa Inggris yang mengalami penyempitan makna secara amelioratif. Metode penelitian yang diterapkan adalah metode deskriptif sinkronik dan diakronik, yaitu metode yang mengilustrasikan paparan yang berkaitan dengan analisis masa lampau dan waktu kini. Data pada penelitian ini sejumlah enam nomina yang diperoleh dari hasil pengamatan pada video liputan yang disiarkan pada televisi. Perubahan makna dalam penelitian ini dipengaruhi oleh beberapa aspek: (a) perubahan makna akibat perubahan lingkungan, (b) perubahan makna akibat tanggapan pemakai bahasa, dan (c) perubahan makna akibat asosiasi. Selain itu, hasil menunjukkan bahwa penyempitan makna berkorelasi dengan homonimi dan polisemi. Perubahan makna kata yang terjadi dapat berhubungan atau tidak berhubungan sama sekali dengan makna sebelumnya. Proses yang cukup panjang dan kesepakatan dari masyarakat merupakan tantangan yang perlu dihadapi agar penyempitan makna dapat berterima.
\end{abstract}

Kata kunci: amerliorasi, penyempitan makna, perubahan makna

\section{A. PENDAHULUAN}

Bahasa Inggris (BI) adalah bahasa yang dipergunakan oleh sejumlah negara sebagai bahasa kenegaraan. Selain itu, BI dinyatakan sebagai lingua franca sekaligus menjadi bahasa internasional sehingga 
digunakan secara luas di seluruh dunia, tidak terkecuali di Indonesia. Kondisi ini mendorong masyarakat di Indonesia untuk mempelajari atau mengkaji BI, terutama pada tataran makna.

Makna merupakan salah satu pokok kajian dalam linguistik. Cabang ilmu linguistik yang mempelajari makna dikenal dengan istilah semantik. Lebih jelasnya, Kriedler (2002: 3) memaparkan bahwa semantik merupakan bidang ilmu linguistik yang mengkaji sistematika dan mekanisme bahasa dalam mengatur dan mengekspresikan makna. Makna secara umum didefinisikan sebagai pesan yang terdapat dalam suatu satuan bahasa. Riemer (2010: 2) menjelaskan bahwa dalam bahasa Inggris "meaning is used to refer to such different things as the idea or intention lying behind a piece of language, the thing referred to by a piece of language, and the translations of words between languages". Suatu kata lazimnya memiliki makna yang melekat secara utuh. Ada pula kata yang memiliki lebih dari satu makna seperti yang diungkapkan Budhiono (2017, hlm. 238) bahwa "kata memiliki makna yang dapat dipahami secara apa adanya dan yang harus dipahami berdasarkan hubungannya dengan kata atau istilah lain dalam sebuah konstruksi". Di samping itu, Wihadi and Fauziah (2019) menjelaskan sejumlah kajian telah dilakukan untuk menelaah variasi makna yang terdapat pada masyarakat bahasa tertentu, khususnya kata yang memiliki makna lebih dari satu.

Setiap kata memiliki esensi makna yang dapat mengalami perubahan seiring dengan berjalannya waktu. Perubahan makna pada suatu kata dapat terjadi secara ekstrem bila dibandingkan dengan makna aslinya (Altakhaineh, 2018). Hal demikian secara semantis berkaitan dengan unsur metafora yang telah berproses secara bertahap atau sporadis dan mendapat pengakuan dari masyarakat bahasa seperti pernyataan yang diungkapkan oleh Hidayati et al. (2018).
Terlebih lagi penelitian itu memaparkan metafora dapat mengakibakan terjalinnya hubungan semantis antara makna baru dengan makna awalnya. Gejala ini dapat ditemukan seperti pada kata button (nomina) yang secara umum diketahui dengan makna kancing. Kancing dapat didefinisikan sebagai benda berbentuk bulat yang terdapat pada baju. Selaras dengan kebutuhan dalam berbahasa, kata itu pada saat ini mengalami perubahan makna sehingga kini button digunakan untuk merepresentasikan benda lain seperti 'tombol'.

Perubahan makna kata yang terjadi dapat mengarah pada penyempitan makna atau dalam kata lain dikenal dengan istilah semantic narrowing. Penyempitan makna adalah gejala kebahasaan yang didasari pemikiran kritis dan perubahan pola pikir yang dialami oleh masyarakat bahasa pada umumnya. Penyempitan makna dipaparkan oleh Riemer (2010, hlm. 374) sebagai tipe perubahan makna yang terjadi guna memberikan gambaran yang lebih spesifik terhadap suatu referen. Perlu adanya suatu acuan yang digunakan untuk menjadi manifestasi dari suatu kata. Kartika (2014, hlm. 188) mendeskripsikan perubahan yang terjadi pada tataran makna itu boleh jadi hanya terbatas pada makna yang menyempit seperti perubahan pada kata misalnya pada kata meat yang awalnya 'makanan' kemudian maknanya menyempit menjadi 'daging'.

Penyempitan makna yang mengarah pada makna positif dikenal sebagai ameliorasi. Altakhaineh (2018) mendeskripsikan ameliorasi merupakan proses penyisipan makna positif pada suatu kata. Penelitian terdahulu ini menelaah perubahan makna yang mengarah pada pejorasi dan ameliorasi pada kelas kata ajektif. Temuannya adalah makna positif pada ajektif dapat mengalami perubahan makna ke arah positif, netral, dan negatif, sedangkan ajektif yang bermakna negatif mengalami 
perubahan ke arah positif. Penelitian lain oleh Wihadi dan Fauziah (2019) memaparkan bahwa kata bermakna kasar dan halus umumnya digunakan dalam masyarakat sesuai dengan kebutuhannya. $\mathrm{Hal}$ ini berkaitan dengan perubahan makna yang menjadi tantangan bagi para peneliti untuk mengkaji lebih dalam lagi mengenai jenis-jenis perubahan makna dan alasan perubahan makna tersebut dapat terjadi.

Penelitian ini membahas penyempitan makna pada nomina dalam BI. Berbeda dengan penelitian Altakhaineh (2018) yang menelaah perubahan makna amelioratif dan pejoratif pada ajektif, penelitian ini menitikberatkan pada penyempitan makna amelioratif. Analisis penyempitan makna merupakan upaya dalam mengidentifikasi makna kata baik dahulu atau yang berlaku pada saat ini. Cruse (2006, hlm. 2) menyatakan "bistoricall diachronic semantics, which deals with the ways in which meanings change over time, may also be included (but less often)". Pemahaman yang luas mengenai sejarah serta kondisi sosial saat makna pada kata berubah merupakan konsekuensi kajian diakronik.

Penelitian ini disusun berdasarkan fenomena kebahasaan yang luput dari perhatian masyarakat. Terdapat beberapa pertimbangan yang harus disesuaikan dengan kebutuhan pembaca. Pertama, pembaca lebih mengenal definisi dan perkembangan perubahan makna, khususnya berkaitan dengan penyempitan makna amelioratif. Kedua, pembahasan akan memaparkan proses dan mekanisme menyempitnya suatu kata. Dengan demikian, penelitian ini dapat mendeskripsikan proses penyempitan makna amelioratif pada kata dalam bahasa Inggris.

\section{B. LANDASAN TEORI}

Studi tentang perubahan makna telah dilakukan oleh para peneliti. Wihadi dan Fauziah (2019) mengungkapkan bahwa para peneliti telah menemukan kata baru yang terbentuk dari hasil perubahan makna. Terlebih lagi, kata tersebut mengalami perubahan makna yang disebabkan oleh suatu kondisi yang terjadi dalam suatu komunitas. Nampaknya gejala ini akan terus terjadi, terutama di kalangan pengguna bahasa milenial karena mereka memiliki gaya komunikasi yang kreatif.

Penelitian yang berkaitan dengan perubahan makna memiliki daya tarik tersendiri. Blank (1999) dalam Altakhaineh (2018) mengelaborasikan enam latar belakang terjadinya perubahan makna. Pertama, pengguna bahasa membutuhkan penamaan baru atau konsep baru, hal ini lumrah ditemukan karena sifat bahasa yang dinamis dan selalu beradaptasi dengan perkembangan yang terjadi di dunia. Pola pikir masyarakat pun akan mengalami perubahan dan kondisi ini dapat mempengaruhi penggunaan bahasa. Pernyataan ini menyiratkan bahwa konsep baru dapat muncul sebagai hasil dari suatu perubahan. Konsep baru itu dapat diungkapkan melalui parafrase. Sebagai contoh pada kata late. Kata ini awalnya menyatakan kedatangan yang terlambat. Akan tetapi, saat ini late dapat digunakan untuk menunjukkan hari yang telah larut malam.

Kedua, konsep abstrak, mengacu pada referen yang tak kasat mata dan umumnya tidak dapat dilihat. Tipe ini berhubungan dengan ranah konseptual yang memiliki referen abstrak atau yang sulit dilihat. Hal ini menjadi sulit bagi pengguna bahasa untuk memahaminya dengan cara menggunakan metafora dan emosi.

Ketiga, perubahan sosiokultural, semenjak bahasa dinyatakan sebagai tindakan sosial, perubahan dalam cakupan bahasa merupakan hasil dari interaksi sosial yang dalam masyarakat. Selain itu, stratifikasi sosial dan kuasa yang ditunjukkan oleh seorang penutur 
bahasa dalam kelompok sosial tertentu dapat menyebabkan perubahan dalam penggunaan bahasa, terutama perubahan makna. Contohnya ketika tahun 2020 dunia digegerkan oleh mewabahnya virus korona (Covid-19) yang tetunya berdampak pada penggunaan bahasa. Terdapat kata yang dipopulerkan oleh media seperti hazardous material suit (hazmat) dan new normal.

Keempat, relasi faktual, tipe ini mengacu pada relasi antara konsep yang dapat membuat nama mentransfer kemungkinan bila nama itu efisien dan dapat mengalami leksikalisasi. Pada dasarnya, kata itu mengalami perubahan secara semantik menjadi kata berpolisemi. Relasi konseptual dapat dibentuk karena terjadinya proses kebahasaan di masyarakat. Salah satu contohnya adalah 'urban' yang merujuk pada perkotaan.

Kelima, kompleksitas dan ketidakberaturan pada leksikon, muncul dari keaadaan penutur bahasa cenderung mengurangi ketidakberaturan leksikal dan kompleksitas dalam bahasa yang digunakan dalam berkomunikasi. Oleh karena itu, penutur melakukan pelesapan leksikal demi mengurangi kata yang kompleks. Contohnya pada premenstrual syndrom, penutur lebih menyengangi menggunakan abreviasi PMS.

Keenam, konsep penanda emosional, satuan bahasa dapat digunakan dalam mengekspresikan suatu keadaan emosional. Kata sorry pada kalimat I am sorry to hear that menandakan adanya kondisi tidak menyenangkan, daripada penggunaan poor pada poor you.

Teori yang digunakan dalam artikel ini adalah teori yang diungkapkan oleh Pateda (1996) dan Riemer (2010) mengenai penyempitan makna serta korelasinya dengan perubahan makna yang bersifat amelioratif. Pateda (1996, hlm. 168) memaparkan bahwa perubahan makna merupakan hasil dari perkembangan pemikiran manusia sebagai pemakai bahasa karena menginginkan agar komunikasinya dengan orang lain berjalan dengan lancar, yang diakibatkan beberapa aspek, di antaranya: (a) perubahan makna akibat perubahan lingkungan, (b) perubahan makna akibat tanggapan pemakai bahasa, dan (c) perubahan makna akibat asosiasi. Teori lain yang dirujuk adalah teori sosiolingustik Holmes (2001). Melalui teori yang diperoleh, data dapat dikembangkan dan dianalisis dengan sistematika yang teratur. Kemudian, data ditelaah dan dijelaskan secara terperinci berdasarkan pada gejala di masyarakat dengan merujuk pada teori.

\section{METODE}

Metode yang digunakan dalam penelitian ini adalah metode analisis deskriptif sinkronik dan diakronik. Mahsun (2005, hlm. 85) mendeskripsikan bahwa paparan sinkronik dan diakronik, bahwa "linguistik sinkronis adalah bidang ilmu bahasa yang menelaah sistem bahasa pada waktu tertentu, sedangkan diakronis adalah bidang linguistik yang menyelidiki perkembangan bahasa dari satu masa ke masa yang lain, serta menyelidiki perbandingan bahasa dengan bahasa yang lain." Metode ini diterapkan berkenaan dengan periode diakronik karena data yang diperoleh berkorelasi dengan periode lampau, sedangkan landasan teori untuk menganalisis sumber data menggunakan teori linguistik kontemporer.

Data yang diolah pada penelitian ini dikumpulkan berdasarkan temuan empiris yang diperoleh dari berbagai liputan televisi. Rentang waktu yang diperlukan untuk melakukan penelitian dan pengumpulan data adalah 2017-2019. Data yang dikumpulkan berupa leksem yang diduga mengalami proses penyempitan makna untuk ditelaah lebih lanjut dengan merujuk pada teori yang relevan.

Data dipilah dan ditelaah berdasarkan makna leksikalnya. Analisis 
komponen makna dilakukan terhadap leksem-leksem dalam satu medan makna dan satuan leksikal, yaitu kesatuan makna yang dapat dijelaskan sampai pada komponen sekecil-kecilnya (Suryatin, 2014, hlm. 45). Dengan demikian, makna awal suatu kata dapat diperoleh dengan menelisik nilai-nilai historisnya

\section{PEMBAHASAN}

Telaah perubahan makna dapat dilakukan dengan dua metode, yaitu dengan menentukan komponen semantis dan makna yang berkaitan seperti yang diungkapkan oleh Nida dalam Anam dan Nirmala (2019). Penelitian terdahulu itu pun mengungkapkan adanya tiga jenis komponen semantis: komponen umum berkaitan dengan setiap unsur leksikal; diagnosis merupakan penentuan komponen antarunit; dan suplemen berasal dari makna konotatif tertentu.

Makna yang merepresentasikan asosiasi netral atau positif merupakan karakter dari makna amelioratif. Pateda (1996, hlm. 176) mengilustrasikan bahwa ameliorasi adalah makna yang menjurus pada hal yang menyenangkan. Sedangkan menurut Saleh (2017, hlm. 49) ameliorasi adalah "perubahan makna yang terjadi karena makna yang baru lebuh luas, tinggi, dan santun dibandingkan dengan makna sebelumnya". Oleh karena itu, makna itu tidak mengandung ungkapan emotif yang bersifat tabu atau vulgar. Ameliorasi bukan merupakan jenis perubahan makna, tetapi karakter makna yang terkandung dalam suatu kata. Moehkardi (2016, hlm. 325) menjelaskan makna baru mungkin saja berasal dari makna yang sudah ada sebelumnya yang telah mengalami perkembangan. Adapun makna yang sama terdapat dalam beberapa kata seperti kata labor dan slave dalam bahasa Inggris yang bermakna 'buruh'. Kedua kata sejatinya memiliki makna yang serupa. Akan tetapi, pada kenyataannya keduanya itu kini memiliki makna yang berbeda. Labor menyatakan seseorang yang bekerja di dalam perusahaan industri, sedangkan slave diinterpretasikan menjadi seseorang yang bekerja pada pihak lain dengan konsekuensi pekerjaan sebagai budak.

Data yang dikumpulkan pada penelitian ini sebanyak enam leksem. Keenam data yang dikumpulkan adalah hasil observasi yang dilakukan pada liputan yang ditayangkan pada siaran televisi. Pengumpulan data dilakukan secara acak untuk menemukan nomina dalam BI yang mengalami penyempitan makna secara amelioratif. Studi kepustakaan dilakukan dengan merujuk pada artikel online dan kamus.

Berikut pemaparan mengenai kata yang mengalami proses penyempitan makna secara amelioratif.

\section{(1) Abaca}

Abaca atau dalam bahasa Latin Musa textilis merupakan jenis tanaman pisang. Kata ini diserap dari kata bahasa Tagalog (abaka) yang bermakna usaha tekstil pengolahan pohon pisang abaca yang dikutip dari laman Britannica ${ }^{1}$, merupakan jenis pohon pisang yang tersebar di Filipina dan beberapa pulau terluar di Sulawesi Utara, bahasa Inggris mulai menggunakan kata abaca mengingat pentingnya pembeda antara pisang abaca dengan pisang lainnya ditinjau dari segi sosio-ekonomi. Perlu diketahui, berdasarkan pernyataan yang diperoleh dari Food and Agriculture Organizations (FAO) of the United Nations (UN) ${ }^{2}$, abaca merupakan salah satu jenis pisang yang tidak dapat dikonsumsi karena tidak memiliki rasa seperti jenis pisang lain pada umumnya. Bagian yang bermanfaat adalah batangnya. Batang pohon abaca mengandung serat yang tinggi dapat digunakan sebagai material pembuatan baju rajutan (Gambar 1).

\footnotetext{
${ }^{1}$ https://www.britannica.com/plant/abaca

2 http://www.fao.org/economic/futurefibres/ fibres/abaca0/en/
} 
Mengingat buah pisang abaca yang tidak dapat diolah sebagaimana layaknya, pemaknaan abaca pada saat ini dimanifestasikan untuk batangnya. Perubahan makna terjadi karena tanggapan pemakai bahasa yang menyatakan bahwa buah yang terdapat pada tanaman tidak tercakup dalam makna abaca. Dengan demikian, dalam proses perubahan maknanya tidak mengindikasikan pada hal yang tidak menyenangkan.

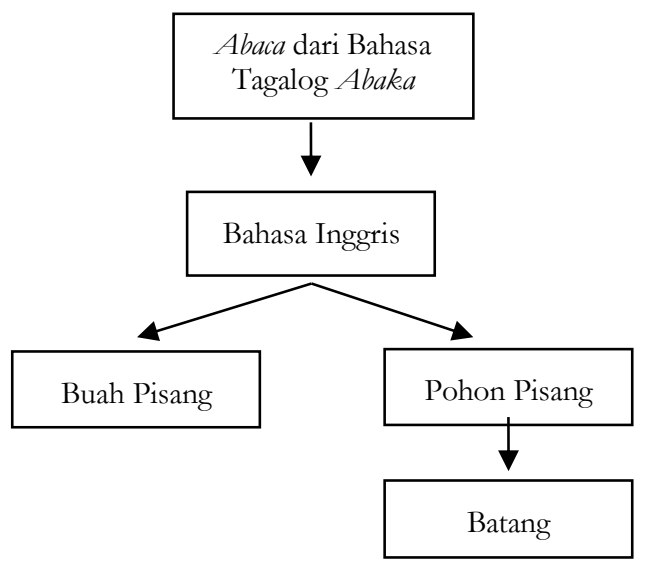

Gambar 1. Proses Penyempitan Makna pada Abaca

\section{(2) Accident}

Accident berkategori kata nomina, tepatnya nomina yang bersifat abstrak. Sebagai nomina, accident pada masa lampau bermakna (a) segala kejadian atau acara yang seharusnya terjadi, misalnya upacara pernikahan, acara keagamaan, kematian; (b) peristiwa yang tidak diharapkan, seperti bencana alam, wabah penyakit, ketidakberuntungan. ${ }^{3}$ Kemudian, kata ini digunakan untuk merepresentasikan suatu kejadian yang tidak diduga. Kejadian yang dimaksud secara umum merujuk pada kecelakaan lalu-lintas yang mengakibatkan cedera pada pengemudi atau penumpang dan menyebabkan kerusakan pada kendaraan

\footnotetext{
${ }^{3}$ https://www.etymonline.com/word/accident
}

atau objek lain yang ada di jalan raya (Gambar 2).

Perubahan makna disebabkan adanya asosiasi yang dapat mendefinisikan suatu kejadian yang terjadi secara tiba-tiba. Dalam bahasa Inggris, kata accident seperti yang telah dipaparkan pada penjelasan sebelumnya tidak memiliki padanan kata lain. Selanjutnya, accident menjadi kata yang memiliki makna ganda. Kini accident dipersempit maknanya seperti yang terdapat dalam Oxford Advanced Learner's Dictionary menjadi: (1) unpleasant event, especially in a vebicle; (2) something that happens unexpectedly and is not planned in advance. Berdasarkan hasil temuan, tidak terdapat makna negatif pada accident setelah maknanya menglami perubahan mengingat makna terdahulu merepresentasikan peristiwa yang kurang menyenangkan.

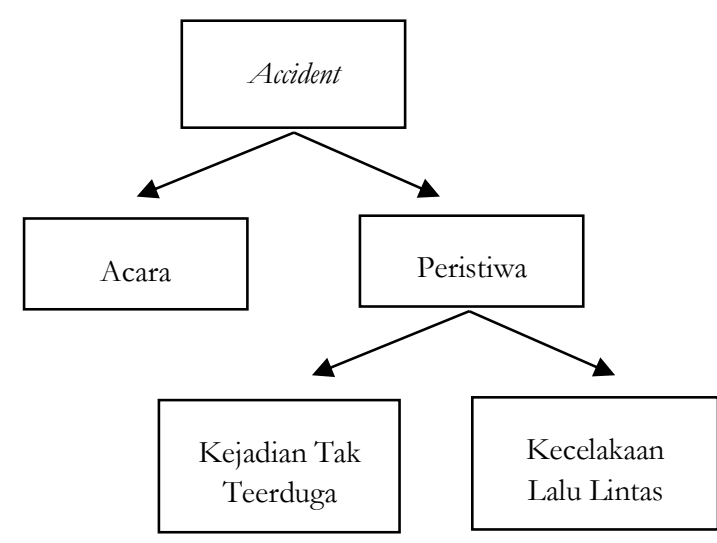

\section{Gambar 2. Proses Penyempitan Makna pada Accident}

\section{(3) Carnival}

Carnival atau dalam bahasa Indonesia popular dikenal dengan istilah karnaval merupakan suatu parade. Kata ini dikenal secara umum sebagai sarana hiburan masyarakat yang identik dengan pertunjukan atraksi yang memukau. Kegiatan seperti ini masih digelar dengan menyuguhkan atraksi berkeliling kota dengan busana yang khas. Pesta itu masih 
diadakan di beberapa negara di Amerika Selatan (Gambar 3).

Perubahan makna pada carnival dikategorikan ke dalam jenis perubahan makna terhadap perubahan lingkungan. Akan tetapi, maknanya diharapkan tidak menunjukkan konsep acara seperti yang diperingati di wilayah Amerika Selatan, khususnya di Indonesia. Konsep karnaval di dunia kini hampir sama, yaitu parade yang diadakan di jalan-jalan protokol dengan menonjolkan seni dan tari pada umumnya. Dengan demikian, kata carnival bermakna amelioratif karena tidak mengandung makna negatif seperti sebelumnya.

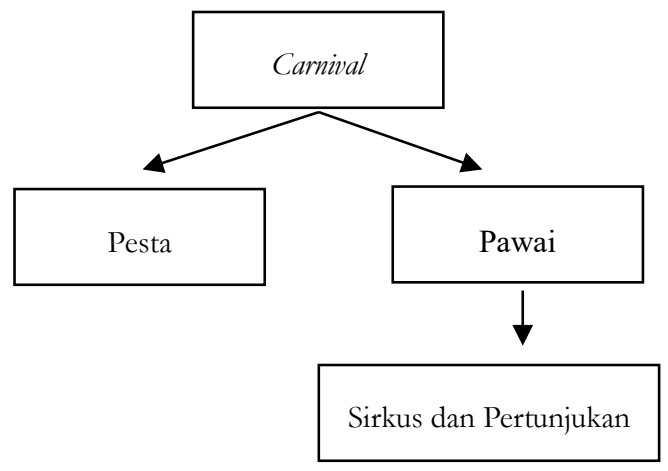

\section{Gambar 3. Proses Penyempitan Makna pada Carnival}

\section{(4) Deer}

Deer berasal dari kata deor dalam bahasa Skandinavia di masa old English sekitar abad ke-11 (Toupin, 2015). Sebelum tahun 1200-1400, deer merupakan perumpamaan bagi monster yang bentuknya menyerupai binatang berkaki empat yang hidup di alam liar. ${ }^{4}$ Seiring berjalannya waktu, pendistribusian narasi legenda mengenai monster itu secara bertahap mulai dilupakan oleh masyarakat pada zamannya. Kata deer pada masa berikutnya mengalami perluasan makna, yaitu menjadi peristilahan bagi binatang buas yang memiliki kaki empat (Gambar 4).

\footnotetext{
${ }^{4}$ https://www.etymonline.com/word/deer
}

Perubahan makna pada deer merupakan perwujudan dari perubahan makna akibat asosiasi. Masyarakat terdahulu mengasosiasikan bentuk dan ciri-ciri pada hewan rusa dari sosok legenda pada masa lampau. Kebiasaan masyarakat terdahulu berburu jenis binatang berwarna coklat terang dan berlari sangat kencang, maka deer tadi digambarkan dalam sosok rusa. Dengan demikian, kata deer bermakna amelioratif karena tidak mengandung makna negatif seperti pada definisi sebelumnya.

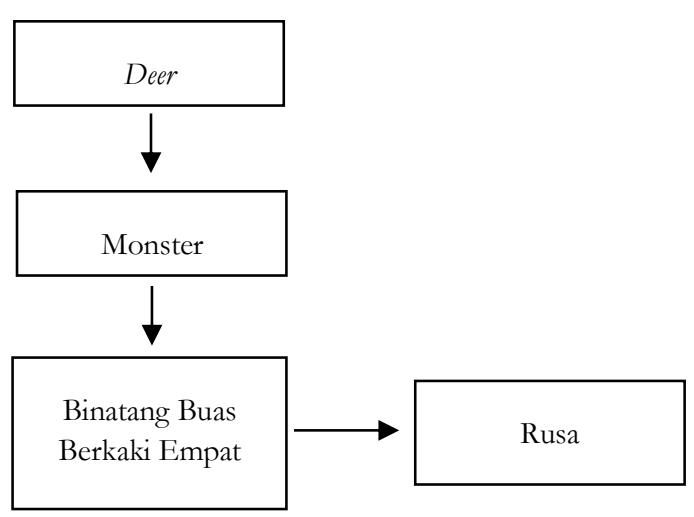

\section{Gambar 4. Proses Penyempitan Makna pada Deer}

\section{(5) Game}

Game dalam bahasa Indonesia tidak asing lagi bagi pengguna komputer dan alat elektronik sejenisnya karena identik dengan hal-hal yang merujuk pada permainan ketangkasan. Akan tetapi, game memiliki beberapa makna lain yang jarang diketahui oleh masyarakat, seperti halnya yang dijelaskan dalam Oxford Advanced Learner's Dictionary menjadi: (1) an activity or a sport with rules in which people or teams compete against each other, (2) an occasion of playing a game; (3) the way in which somebody plays a game; (4) wild animals or birds that people bunt for sport or food, etc. Berdasarkan keempat pengertian itu, makna katanya menyempit karena makna game pada (1), (2), dan (3) menegaskan dominasi dengan terminologi permainan (Gambar 5). 
Bagi penutur bahasa Inggris asli tetunya tidak akan menemukan kesulitan dalam menginterpretasikan kata game. Namun, bagi penutur asing akan menimbulkan kendala untuk mendefinisikan kata dengan makna tak tunggal. Temuan ini dipertegas oleh Suwarti dan Budiyono (2015) yang menyatakan bahwa adanya kendala bagi penutur bahasa yang bukan bahasa ibu untuk memahami suatu kata, termasuk kata-kata dengan makna yang baru. Contohnya terdapat pada cerpen The Most Dangerous Game yang dikarang oleh Richard Connell pada tahun 1924. Pembaca secara harfiah menerjemahkannya dengan "Permainan yang Paling berbahaya". Namun, pengertian yang tepat untuk menginterpretasikan judul itu adalah "Mangsa yang Paling Berbahaya.

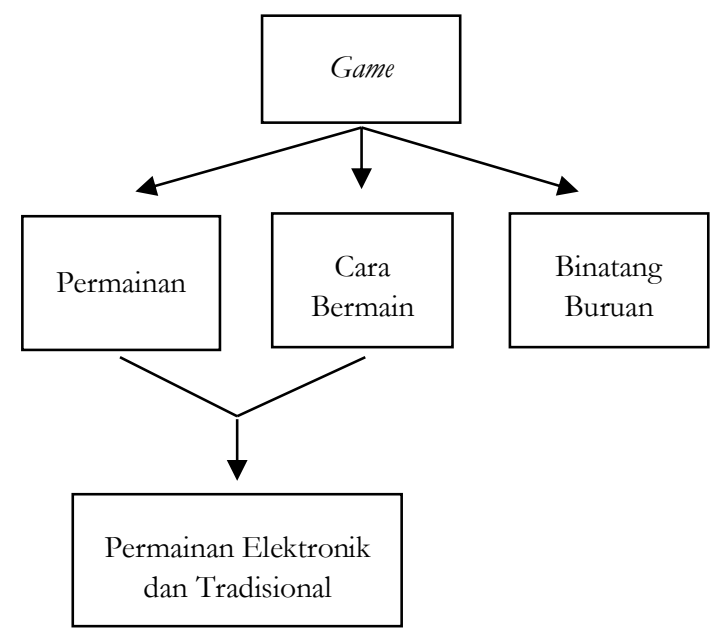

\section{Gambar 5. Proses Penyempitan Makna pada Game}

Penyempitan makna pada kata game disebabkan oleh perubahan makna akibat tanggapan pemakai bahasa karena adanya kebutuhan dalam mendefinisikan suatu kegiatan yang tidak ada padanan katanya. Kata itu dikategorikan ke dalam kata yang memiliki makna ganda. Dengan demikian, tidak terjadi perubahan makna yang menjurus pada hal negative.

\section{(6) Goal}

Goal adalah kata yang memiliki dua kelas kata, yaitu nomina dan verba. Dalam pengertiannya pada masa lampau, goal dimaknai sebagai hasil atau pencapaian dari usaha yang telah dilakukan; tujuan; atau hasil akhir. ${ }^{5}$ Tujuan yang dimaksud merupakan rencana yang digagas oleh seseorang dalam mencapai suatu hasil yang maksimal. Namun, kini maknanya populer digunakan dalam bidang olahraga, khususnya sepak bola seperti yang dijelaskan dalam Oxford Advanced Learner's Dictionary menjadi: (1) (in football, bockey, etc) a wooden frame with a net into which players must kick or bit the ball in order to score point; (2) the act of kicking or bitting the ball into the goal; (3) something that you hope to achieve (Gambar 6).

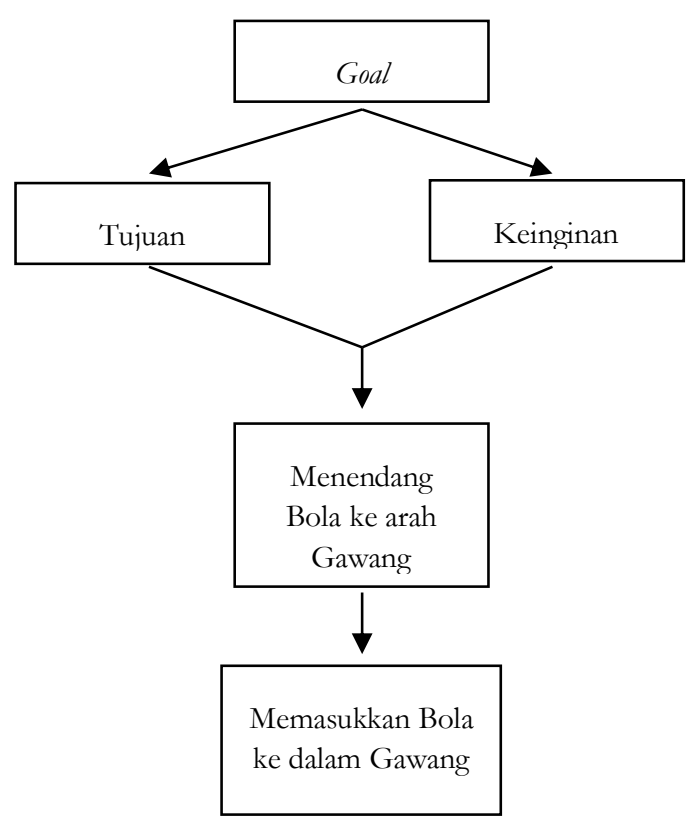

\section{Gambar 6. Proses Penyempitan Makna pada Goal}

Perubahan makna pada kata goal dipengaruhi oleh perubahan makna akibat asosiasi. Dalam permainan olahraga bola

\footnotetext{
${ }^{5}$ http:/ / www.dictionary.com/browse/goal?s $=\mathrm{t}$
} 
ini, goal terjadi ketika seorang pemain berhasil memasukkan bola ke dalam gawang lawan. Berdasarkan temuan ini, makna goal kemudian berpolisemi tetapi tidak secara permanen mengalami perubahan makna. Peristiwa masuknya bola ke dalam gawang tersebut merupakan representasi dari makna kata goal itu sendiri. Apabila menguraikan makna kata tersebut, tidak terjadi perubahan makna yang menjurus pada hal negatif.

\section{PENUTUP}

Penyempitan makna merupakan perkembangan bahasa yang lazim ditemukan dalam masyarakat bahasa yang produktif dan biasanya terjadi karena perkembangan zaman dan kebutuhan masyarakat dalam memberikan makna pada kata. Berdasarkan hasil yang ditemukan, ditarik beberapa simpulan. Terdapat gejala perubahan makna dalam proses penyempitan makna. Perubahan makna yang dimaksud didapat dari perkembangan makna yang berlandaskan pada homonimi atau polisemi. Data menunjukkan adanya perubahan makna yang masih ada hubungan dan tidak berhubungan sama sekali dengan makna sebelumnya. Penyempitan makna menegaskan indikasi perubahan makna amelioratif. Data yang dianalisis menguraikan bahwa penyempitan makna pada sejumlah kata tidak menunjukan adanya perubahan makna pejoratif.

Penyempitan makna dapat terjadi dalam periode yang panjang, bergantung pada keputusan masyarakat untuk menyematkan makna yang digunakan sesuai dengan kebutuhan. Penelitian ini masih memiliki keterbatasan sehingga dibutuhkan proses lebih lanjut guna mendapatkan hasil yang lebih optimal. Penelitian berikutnya dapat menelaah komparasi antara makna dalam beberapa kamus dan memaparkannya dengan lebih terperinci. Dengan demikian, langkah itu diharapkan mempermudah dalam pendefinisian makna-makna lain yang belum dipahami oleh masyarakat.

\section{DAFTAR PUSTAKA}

Altakhaineh, A. R. M. (2018). The Semantic Change of Positive vs. Negative Adjectives in Modern English. Lingua Posnaniensis, 60(2), 25-36.

https://doi.org/10.2478/linpo-201800010

Anam, M. K. \& Nirmala. (2019). Semantic Changes of English Loanwords in Radar Kediri Daily Newspaper Headlines. Parole: Journal of Linguistics and Education, 9(2), 8089.

https://doi.org/10.14710/parole.v9i 2.80-89

Ardiansyah, E. A., Indriani, L. M., \& Riyanto, S. (2014). Jargon Peretas yang Dibentuk melalui Proses Perluasan Makna. Humaniora, 26(3), 328-336. https://doi.org/10.22146/jh.6191

Budhiono, H. R. (2017). Leksikon Alat dan Aktivitas Bertanam Padi dalam Bahasa Jawa. Kandai, 13(2), 235-248. https://doi.org/10.26499/jk.v13i2.2 10

Cruse, A. (2006). A Glossary of Semantics and Pragmatics. Edinburgh: Edinburgh University Press Ltd.

Dworkin, S. N. (2006). Recent Developments in Spanish (and Romance) Historical Semantics. In Selected Proceedings of the 8th Hispanic Linguistics Symposium, ed. Timothy L. Face and Carol A. Klee, 50-57. Somerville, MA: Cascadilla Proceedings Project.

Encyclopedia Britanica. Abaca. (2020, March 2020). Retrieved from https://www.etymonline.com/word /deer.

Food and Agriculture organization of the United Nation. Abaca. (2020, March 2020). Retrieved from http://www.fao.org/economic/futu refibres/fibres/abaca0/en/ 
Hidayati, Ilham, \& Fani, F. (2018). Semantic Change Analysis on Film "The King's Speech". Journal of English Language Teaching and Linguistics, $\quad 11(2), \quad$ 8-13. https://doi.org/10.31764/LELTJ.V 12I2.747

Holmes, J. (2001). An introduction to sociolinguistics. USA: Longman.

Kartika. (2014). Proses Perubahan Kata anyar, ku, ti, keur, dan sok dalam Bahasa Sunda. Metalingua, 12(2), 187194.

http://dx.doi.org/10.26499/metalin gua.v12i2.25

Kreidler, S. W. (2002). Introducing English Semantics. New York: Taylor \& Francis.

Mahsun. (2005). Metode Penelitian Bahasa. Jakarta: Rajawali Pers.

Moehkardi, R., R. (2016). Patterns and Meanings of English Words through Word Formation Processes of Acronyms, Clipping, Compound and Blending Found in Internet-Based Media. Humaniora, 28(3), 324-338. https://doi.org/10.22146/jh.22287

Online Etimology Dictionary. Accident. (2020, April 2020). https://www.etymonline.com/word /accident.

Pateda, M. (1996). Semantik leksikal. Jakarta: Rineka Cipta.

Riemer, N. (2010). Introducing semantics. Cambridge, United Kingdom: Cambridge University Press.
Saleh, R. (2017). Pergeseran makna dalam berita tentang sampah di GORIAU. Kandai, 12(1) 47-60. https://doi.org/10.26499/jk.v13i1.9 7

Suryatin, E. (2014). Analisis Semantik Verba Bermakna 'Menyakiti' dalam Bahasa Banjar. Metalingua, 43(1), 4356.

http://dx.doi.org/10.26499/metalin gua.v12i1.39

Suwarti \& Budiyono. (2015). Struktur Semantik Soal Cerita Matematika untuk Siswa Kelas Rendah Sekolah Dasar. Litera, 14(2), 262-276. https://doi.org/10.21831/ltr.v14i2.7 203

Suyitno, I. (2017). The Cultural Meaning of Traditional Expressions in Daily Speech of Using Community at Banyuwangi. Humaniora, 29(2), 215223.

https://doi.org/10.22146/jh.25896

Toupin, F. (2015). About Plural Morphology and Game Animals: from Old English to Present-Day English. Lexis, 9. https://doi.org/10.4000/lexis.964

Wihadi, M., \& Fauziah, S. (2019). Pinpointing semantic shifts in three diverse generations of Kuningan Region. English Journal Literacy UTama, 3(2), 89-94. https://doi.org/10.33197/ejlutama.v ol3.iss2.2019.262 